\title{
In vitro Immunomodulatory Effect from Edible Green Seaweed of Caulerpa lentillifera Extracts on Nitric Oxide Production and Phagocytosis Activity of RAW 264.7 Murine Macrophage Cells
}

\author{
Sofa Fajriah ${ }^{1, *}$, Sri Handayani ${ }^{2}$, Ellya Sinurat ${ }^{3}$, Megawati Megawati ${ }^{1}$, Akhmad Darmawan ${ }^{1}$, Hariyanti Hariyanti ${ }^{4}$, Rizna Triana Dewi ${ }^{1}$, \\ Abdi Wira Septama ${ }^{1}$ \\ ${ }^{1}$ Research Center for Chemistry, Indonesian Institute of Sciences, Kawasan PUSPIPTEK Serpong, Kota Tangerang Selatan, Banten, INDONESIA. \\ ${ }^{2}$ Research Unit for Natural Product Technology, Indonesian Institute of Sciences, J. Jogja-Wonosari, Gunung Kidul, Yogyakarta, INDONESIA. \\ ${ }^{3}$ Research and Development Center for Marine and Fisheries Product Processing and Biotechnology, Ministry of Marine Affairs and Fisheries RI, \\ JI KS Tubun Petamburan VI, Slipi, Central Jakarta, INDONESIA. \\ ${ }^{4}$ Faculty of Pharmacy and Sciences, Universitas Muhammadiyah Prof. DR. HAMKA, Kebayoran Baru, Jakarta, INDONESIA.
}

\begin{abstract}
Background: Caulerpa lentillifera is edible macroalgae which has several biological properties. This marine plant also contains beneficial secondary metabolites that can be used for treatment and prevent several deficiencies. Objectives: This research was conducted to evaluate immunomodulatory effect on nitric oxide production and phagocytosis of RAW 264.7 murine macrophage cells from edible green seaweed of $C$. lentillifera extract. Methods: Extraction was applied to obtained ethanol extract, water extract and insoluble fraction. Alamar blue inclusion method was used to determine cytotoxicity and proliferation of RAW 264.7 after treated with sample. Griess assay using colourimetric commercial kits was selected to evaluate NO production and phagocytosis effect of samples was determined using phagocytic kit. Results: $C$. lentillifera extracts did not show any cytotoxic effect against RAW 264.7 macrophage. One hundred $\mu \mathrm{g} / \mathrm{mL}$ of water extract increased the production of nitrite oxide. This extract revealed suspected-giant cells formation as a results of phagocytosis activity. The extract of $C$. lentillifera also enhanced phagocytosis activity
\end{abstract}

of murine macrophage against $E$. coli. C. lentillifera extract enhanced activity of RAW 264.7 murine macrophage by increasing NO production and phagocytosis activity. This extract also caused suspected-giants' cells as indicator of phagocytosis effect. Conclusion: This result provides an insight that the potency of $C$. lentillifera extract as immunostimulant. Key words: Caulerpa lentillifera, Immunomodulatory, Macrophage, Nitric oxide, Phagocytosis.

Correspondence

Dr. Sofa Fajriah

Research Center for Chemistry, Indonesian Institute of Sciences, Kawasan PUSPIPTEK Serpong, Kota Tangerang Selatan, Banten-15314, INDONESIA.

Phone: +62-21-7560929

Email: sofafajriah@gmail.com

DOI: 10.5530/jyp.2020.12.87

\section{INTRODUCTION}

The immune system provides homeostasis mechanism within the body in healthy host. Immunomodulator is a substance that can modify immune functions either up or down its activity. ${ }^{1}$ Professional phagocytes including macrophage play a fundamental role in defensive mechanism against pathogens. In response to invading bacteria, phagocyte cell will migrate towards the site of infection followed by engulfment of foreign materials through phagocytosis activity.,3 Macrophage also enables to produce various chemical intermediates such as nitric oxide (NO) and hydrogen peroxide $\left(\mathrm{H}_{2} \mathrm{O}_{2}\right)$, as well as inflammatory mediators that can eliminate bacteria or cause of infection in the host. ${ }^{4}$ The use of immunomodulator is important to gain defense response of the host and it has become a promising therapeutic strategy for the treatment of various disorders, including immunodeficiency. Moreover, immunomodulator can also prevent the host from several ailments due to malfunction of the immune system. ${ }^{5}$ Thus, it has been proposed that modulation phagocyte cell by enhancing its activity could be used a basis for the development of immunostimulant agents.

The natural product is a potential source of new drugs. Nowadays, the application of marine seaweed has become prominent for discovering and development of new therapeutic agents. ${ }^{6}$ Macroalgae which contains bioactive compounds has been evaluated regarding its potency as a functional ingredient for human health. ${ }^{7}$ Caulerpa lentillifera is edible seaweed that has been cultivated in Indonesia (Takalar, South Sulawesi). Our previous study showed that C. lentillifera contained high protein $(14.4 \%)$, dietary fibre $(8.5 \%)$, carbohydrate $(32.95 \%)$ and low lipid $(0.84 \%){ }^{8}$ It has been reported that this plant exhibits several pharmacological properties, such as immunomodulator, antimicrobial, antidiabetic, anti-fungal and anti-cancer. ${ }^{9-12}$ C. lentillifera also possessed strong anti-oxidant activity due to their phenolic compound. ${ }^{13,14}$ Some bioactive compounds have also been isolated from this plant, such as clionasterol, 1,4 $\alpha$-glucan dan 1,3- $\beta$-glucan. ${ }^{13,12}$ $\beta$-glucans showed potential for treating several diseases and recognized as potent immunological stimulators in humans. ${ }^{15}$ Therefore, the study was undertaken to evaluate immunomodulatory activity towards macrophage cell from edible green seaweed of $C$. lentillifera extracts and compared with 1,3- $\beta$-glucan.

\section{MATERIALS AND METHODS}

\section{Plant materials}

Seaweed (Caulerpa lentillifera) were collected from Takalar, Makassar, South Sulawesi, Indonesia (cultivating seaweed). The material was identified at Research Center for Oceanography, LIPI. The plant material was hot air oven-dried at $50^{\circ} \mathrm{C}$ and ground to a powder (>80 mesh). 


\section{Extraction}

The powdered of seaweed was soaked with ethanol, then filtrated. The ethanol extract (CL-EE) was obtained by removing the organic solvent under reduce pressure. Meanwhile, the residue was then re-extracted with water for $3 \times 6 \mathrm{~h}$, at $80^{\circ} \mathrm{C}$, followed by addition of ethanol with ratio $1: 2$ to produce water extract (CL-W) and insoluble fraction (CL-In).

\section{Cell culture}

Murine macrophage RAW 264.7 was cultured in complete medium containing RPMI-1640 media supplemented with $10 \% \mathrm{v} / \mathrm{v}$ fetal bovine serum and $1 \% \mathrm{v} / \mathrm{v}$ penicillin-streptomycin in $25 \mathrm{~cm}^{2}$ T-Flask (GIBCO, USA). The cells were incubated in humidified atmosphere with $5 \% \mathrm{CO}_{2}$ at $37^{\circ} \mathrm{C}$

\section{Cell proliferation assay}

Cell proliferation was quantified using colorimetric assay. In brief, macrophage RAW 264.7 cell $\left(1 \times 10^{4}\right.$ cells/well $)$ was platted into 96 -wells plate. Afterward, various concentration of samples (10, 25, 50 and 100 $\mu \mathrm{g} / \mathrm{mL}$ ) were added each well and incubated for $24 \mathrm{~h}$ at $37^{\circ} \mathrm{C}$ under $5 \%$ $\mathrm{CO}_{2}$. After incubation, $50 \mu \mathrm{L}$ of Alamarblue ${ }^{\mathrm{TM}}$ solutions was added into each well and incubated for $4 \mathrm{~h}$. Next, $150 \mu \mathrm{L}$ of an absolute DMSO was added after aspiration of media. The cell proliferation was measured using a microplate reader at 560/590 nm (Varioskan Flash, Thermo Scientific). A percentage relative to the proliferation of control cells was obtained.

\section{Measurements of nitric oxide (NO) production}

The amount of nitrite, an oxidized product, in the cell culture supernatants were measured in order to calculate the amount of NO. The assay was performed using colourimetric commercial kits (Griess Reagent G2930-Promega, USA). LPS was used as a positive control. Briefly, RAW 264.7 cells were seeded at a density of $5 \times 10^{3}$ cells/well in 96-well cell culture plates. Cell suspensions were then treated with various concentrations of each sample $(10,25,50$ and $100 \mu \mathrm{g} / \mathrm{mL})$ or 500 ng/mL LPS (Sigma-Aldrich Co., USA). The treated cell suspension was then incubated for $24 \mathrm{~h}$ at $37^{\circ} \mathrm{C}$ under $5 \% \mathrm{CO}_{2}$. Cell culture supernatant was mixed with Griess reagent (1:1) in a new 96-well plate. Reading was taken at $520 \mathrm{~nm}$ using a microplate reader. Nitrite concentrations were determined.

\section{Phagocytosis assay}

A modified protocol phagocytic kit (Cayman-500290, USA) was used to determine phagocytosis activity. In brief, RAW 264.7 cells were seeded in 96 -well cell culture plates $\left(5 \times 10^{3}\right.$ cells/well) were treated with various concentrations of each sample $(10,25,50$ and $100 \mu \mathrm{g} / \mathrm{mL})$ or $500 \mathrm{ng} / \mathrm{mL}$ LPS (positive control) (Sigma-Aldrich Co., USA) and then incubated for $24 \mathrm{~h}$ at $37^{\circ} \mathrm{C}$ under $5 \% \mathrm{CO}_{2}$. Next, $2 \mu \mathrm{l} / \mathrm{mL}$ latex bead-FITC was added to each well and incubated for $3 \mathrm{~h}$, washed with buffer solution, quenched with $10 \mu \mathrm{l}$ trypan blue quenching solution for $1 \mathrm{~min}$ and washed again with buffer solution. The absorbance of phagocytic cells was measured using a microplate reader at 485/535 nm (Varioskan Flash, Thermo Scientific).

\section{Statistical analysis}

Statistical analysis was performed using Student's $t$ test (Excel 2013 software; Microsoft, Redmond, WA). $P$ values less than 0.05 were considered significant.

\section{RESULTS}

\section{Extraction}

The extraction of $C$. lentillifera using various solvents and methods produced per cent (\%) yield of ethanol extract (CL-EE), water extract (CL-WE) and insoluble fraction (CL-In) were 12, 8 and 6\% respectively.

\section{Measurements of nitric oxide (NO) production}

The effect of the extract in NO secretion was determined by measuring the nitrite content in the culture medium. As shown in Table 1 , the various concentration of extracts and LPS significantly $(p<0.05)$ increased nitrite level compared to the untreated cell and only high concentration of $\beta$ glucan enabled to elevate nitrite level significantly $(p<0.05)$ on cells.

\section{Phagocytosis assay}

The phagocytosis activity of treated RAW 264.7 cells using phagocytosis assay. The results showed that some of RAW 264.7 cells with LPS, $\beta$ glucan and seaweed extracts treatment performed suspected-giant cells formation as a results of phagocytosis activity. As shown in Figure 1, $C$. lentillifera extracts and $\beta$ - glucan $(p<0.05)$ showed phagocytosis activity compared to untreated cells $(p<0.05)$.

\section{DISCUSSION}

Beta $(\beta)$ glucan, known as an active component in seaweed, was selected as a marker. It has been known that $C$. lentillifera has several medicinal properties including modulation of immune cells. In this study, RAW 264.7 cell line was selected to assess immunomodulatory effect of $C$. lentillifera extracts. In order to know the cytotoxic effect of this extract against macrophage, viability test was performed by using alamar blue assay. ${ }^{16}$ It showed that percent (\%) viability all test was greater than $80 \%$ after $24 \mathrm{~h}$ incubation. These results indicated in all tested concentration were non-toxic and it can be used for further experiments.

Macrophage plays an important role to modulate the immune system. This cell enables to kill invading pathogens through phagocytosis activity. In response to infection, macrophage also releases some inflammatory mediators, cytokines as well as free radical. ${ }^{17}$ Nitrite oxide (NO) is one of the important indicators for inflammation. Increasing of

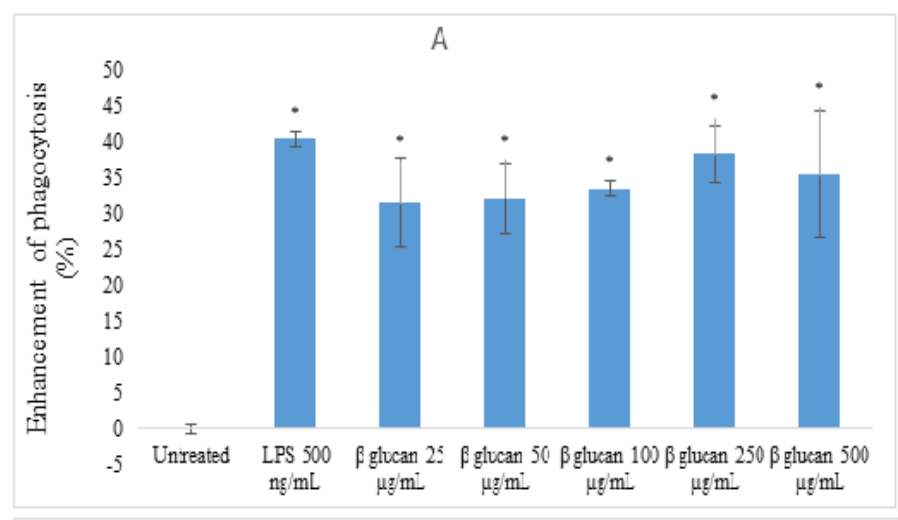

B

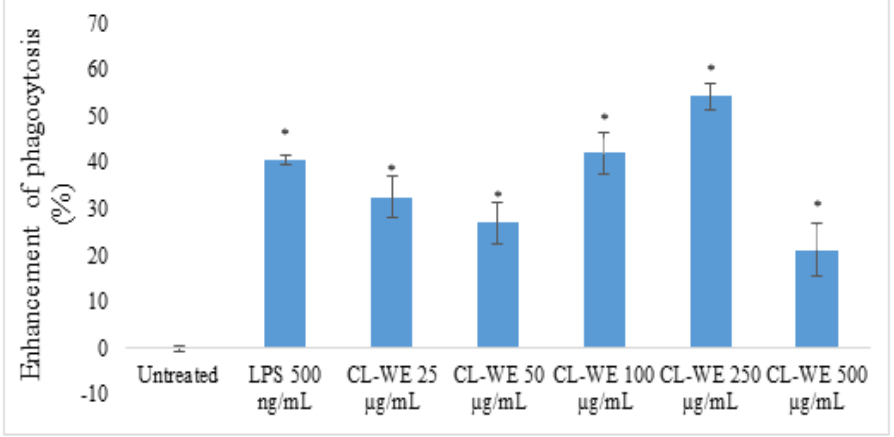

Figure 1: The effect of samples; A. $\beta$ glucan, B. CL-WE (Caulerpa lentillifera Water Extract) on phagocytic activity of RAW 264.7 murine macrophage cells. (mean $\pm \mathrm{SEM}, \mathrm{n}=3$ ). ${ }^{*}$ v value $<0.05$ (student $t$-test) was considered to indicate significance vs untreated cells. 
NO production in macrophages will stimulate immune cells activity in the host. Therefore, in this study, macrophage was selected as in vitro cell model. Lipopolysaccharide (LPS) is used in this research is an endotoxin found in the outer membrane of Gram-negative bacteria. ${ }^{18}$ It can trigger activation of immune cells, due to its function, LPS was selected as a positive control in regard of immuno-stimulant. The effect of the extract in NO secretion was determined by measuring the nitrite content in the culture medium. As shown in Table 1, the various concentration of extracts and LPS significantly $(p<0.05)$ increased nitrite level compared to the untreated cell and only high concentration of $\beta$ glucan enabled to elevate nitrite level significantly $(p<0.05)$ on cells. This finding exhibited that $C$. lentillifera extract in all tested concentrations and $\beta$ glucan induce production of NO on RAW 264.7 cells. This result was in aggreement with previous study which reported that polysaccharides from $C$. lentillifera possessed immunostimulatory activity by increasing the secretion of NO and inflammatory cytokines. ${ }^{19}$ In addition, polysaccharides derived from this algae also enabled to stimulate NO production on murine macrophage. ${ }^{20}$

Phagocytosis is a fundamental function of immune cells to eliminate foreign materials including pathogens. ${ }^{21}$ In order to know correlation between NO secretion and phagocytosis, then we also observed the phagocytosis activity of treated RAW 264.7 cells using phagocytosis assay. The results showed that some of RAW 264.7 cells with LPS, $\beta$ glucan and seaweed extracts treatment performed suspected-giant cells formation as a results of phagocytosis activity. As shown in Figure 1, C. lentillifera extracts and $\beta$ - glucan $(p<0.05)$ showed phagocytosis activity compared to untreated cells $(p<0.05)$. However, dependent concentration response was not found in this study. Amongst all of tested sample, $100 \mu \mathrm{g} / \mathrm{mL}$ of CL-WE and $\beta$-glucan $(250$ and $500 \mu \mathrm{g} / \mathrm{mL}$ ) produced phagocytosis activity which were similar to LPS as positive control. Overall, it can be seen that CL-WE enable to enhance phagocytosis activity as one indicator of immuno-stimulant. This result was in agreement with previous studies. It has been reported that polysaccharides isolated from C. lentillifera promoted proliferation of macrophage. This compound also enhanced phagocytosis activity of immune cells. ${ }^{20}$ Another study

Table 1: The effect of samples on NO production of RAW 264.7 murine macrophage cells (mean \pm SEM, $n=3$ ).

\begin{tabular}{ccc|}
\hline Sample & Concentration & $\begin{array}{c}\text { Concentration of nitrite } \\
(\mu \mathrm{M})\end{array}$ \\
\hline Untreated & - & $1.3 \pm 0.1$ \\
LPS & $500 \mathrm{ng} / \mathrm{mL}$ & $2.9 \pm 0.1^{*}$ \\
$\beta$ glucan & $25 \mu \mathrm{g} / \mathrm{mL}$ & $1.5 \pm 0.2$ \\
& $50 \mu \mathrm{g} / \mathrm{mL}$ & $1.4 \pm 0.1$ \\
& $100 \mu \mathrm{g} / \mathrm{L}$ & $1.9 \pm 0.1^{*}$ \\
& $250 \mu \mathrm{g} / \mathrm{L}$ & $1.9 \pm 0.2^{*}$ \\
& $500 \mu \mathrm{g} / \mathrm{L}$ & $2.7 \pm 0.5^{*}$ \\
CL-WE & $25 \mu \mathrm{g} / \mathrm{mL}$ & $1.7 \pm 0.1^{*}$ \\
& $50 \mu \mathrm{g} / \mathrm{mL}$ & $1.6 \pm 0.1^{*}$ \\
& $100 \mu \mathrm{g} / \mathrm{mL}$ & $1.9 \pm 0.2^{*}$ \\
& $250 \mu \mathrm{g} / \mathrm{mL}$ & $2.5 \pm 0.3^{*}$ \\
& $500 \mu \mathrm{g} / \mathrm{mL}$ & $2.7 \pm 0.3^{*}$ \\
\hline
\end{tabular}

${ }^{\star} P$ value $<0.05$ (student $t$-test) was considered to indicate significance vs untreated cells.

CL-WE (Caulerpa lentillifera Water Extract) also reported that polysaccharides derived from seaweed was able to modulate macrophage function. ${ }^{22}$ It has been known that seaweed and its active compound enabled to enhance immune system in response of invading pathogens. Polysaccharide is a major active compound derived from seaweed which has possessed immunomodulatory activity. Sulfated polysaccharides derived from Laminaria ochroleuca, Porphyra umbilicalis and Gelidium corneum were able to increase the proliferation of murine macrophage. ${ }^{23}$ Recently study showed that $C$. lentillifera contain sulfated polysaccharide. ${ }^{24}$ Furthermore, sulfated polysaccharides from Caulerpa cupressoides Var. Flabellata exhibited strong activity in enhancing activity of innate immune cells. This compound increased the secretion of proinflammatory cytokines including IL- 6 and TNF- $\alpha$, as well as intracellular reactive oxygen species. ${ }^{25}$ This finding proposed that seaweed, an edible plant as a source of functional food which provide many beneficial effects for health including immunomodulator.

\section{CONCLUSION}

In conclusion, C. lentillifera extract derived from cultivation contained various nutrients, as well as active components, can enhance the immune response. This extract increased the NO secretion on murine macrophage and also enabled to raise phagocytosis activity of phagocyte cell. This finding indicates that $C$. lentillifera extract has potential as immunomodulatory agents.

\section{ACKNOWLEDGEMENT}

We wish to thank to Ministry of Research and Technology/National Agency and Research Innovation and LPDP-Ministry of Finance RI for providing a grant to carry out this. We also thank Prof. Dr. Edy Meiyanto from Cancer Chemoprevention Research Center (CCRC), Faculty of Pharmacy, Universitas Gadjah Mada, Indonesia for providing RAW 264.7 cells.

\section{CONFLICT OF INTEREST}

The authors declare that they have no conflict of interest.

\section{ABBREVIATIONS}

NO: Nitric oxide; LPS: Lipopolysaccharide; IL: Interleukin

\section{REFERENCES}

1. Rasheed HMF, Rasheed F, Qureshi AW, Jabeen Q. Immunostimulant activities of the aqueous methanolic extract of Leptadenia pyrotechnica, a plant from Cholistan desert. J Ethnopharmacol. 2016;186:244-50.

2. Viladomiu M, Hontecillas R, Bassaganya-Riera R. Modulation of inflammation and immunity by dietary conjugated linoleic acid. Eur J Pharmacol. 2016;785:8795.

3. Babior BM. The NADPH oxidase of endothelial cells. IUBMB Life. 2000;50(45):267-9.

4. Beutler B. Inferences, questions and possibilities in Toll-like receptor signaling. Nature. 2004;430(6996):257-63

5. Bonfim-Mendonça PDS, Capoci IRG, Tobaldini-Valerio FK, Negri M, Svidzinski TIE. Overview of $\beta$-Glucans from Laminaria spp.: Immunomodulation properties and applications on biologic models. Int J Mol Sci. 2017;18(9):1629.

6. Talluri VP, Kandula SK, Saladi RV. Identification of seaweeds from North Visakhapatnam sea coast exhibiting immunomodulatory activity using Balb/c models. Reg Eng Trans Med. 2017;3(2):70-4

7. Yeganeh S, Adel M. Effects of dietary algae (Sargassum ilicifolium) as immunomodulator and growth promoter of juvenile great sturgeon (Huso huso Linnaeus, 1758). J App Phycol. 2019;31(3):2093-102.

8. Sinurat E, Fajriah, S. The chemical properties of seaweed Caulerpa lentilifera from Takalar, South Sulawesi. IOP Conference Series: Materials Science and Engineering 2019;546(042043):1-5.

9. Maeda $\mathrm{R}$, Ida $\mathrm{T}$, Ihara $\mathrm{H}$, Sakamoto $\mathrm{T}$. Immunostimulatory activity of polysaccharides isolated from Caulerpa lentillifera on macrophage cells. Biosci Biotech Biochem. 2012;76(3):501-5.

10. Roohinejad S, Koubaa M, Barba FJ, Saljoughian S, Amid M, Greiner R. Application of seaweeds to develop new food products with enhanced shelf-life, quality 
and health-related beneficial properties. Food Res Int. 2017;99:1066-83.

11. Sharma BR, Rhyu DY. Anti-diabetic effects of Caulerpa lentillifera: Stimulation of insulin secretion in pancreatic $\beta$-cells and enhancement of glucose uptake in adipocytes. Asian Pac J Trop Biomed. 2014;4(7):575-80

12. Fajriah S, Sinurat E, Megawati M, Darmawan A, Meilawati L, Handayani $S$, et al. Identification of $\beta-1,3-$ Glucan and $\alpha$-Glucosidase Inhibitory Activity from Seagrape Caulerpa lentillifera Extracts. AIP Conference Proceeding. 2018;2024(1):020026.

13. Shevchenko NM, Burtseva YV, Zvyagintseva TN, Makar'eva TN, Sergeeva OS, Zakharenko AM, et al. Polysaccharides and sterols from green algae Caulerpa lentillifera and C. sertularioides. Chem Nat Comp. 2009;45(1):1-5

14. Konishi T, Nakata I, Miyagi Y, Tako M. Extraction of $\beta-1,3$ Xylan from Green Seaweed, Caulerpa lentillifera. J Appl Gly. 2012;59(4):161-3.

15. Chen J, Seviour R. Medicinal importance of fungal $\beta-(1 \rightarrow 3),(1 \rightarrow 6)$-glucans. Mycol Res. 2007;111(6):635-52.

16. Udin Z. Cytotoxic activity of xanthorrhizol from Curcuma xanthorriza Roxb.'s volatile oil toward YMB-1 breast cancer cell. Jurnal Kimia Terapan Indonesia. 2013;15(1):23-9.

17. Ren Z, Qin T, Qiu F, Song Y, Lin D, Ma Y, et al. Immunomodulatory effects of hydroxyl ethylated Hericium erinaceus polysaccharide on macrophages RAW264.7. Int J Biol Macromol. 2017;105:879-85.

18. Wang J, Guo C, Wei Z, He X, Kuo J, Zhou E, et al. Morin suppresses inflammatory cytokine expression by downregulation of nuclear factor$\kappa \mathrm{B}$ and mitogen-activated protein kinase (MAPK) signaling pathways in lipopolysaccharide-stimulated primary bovine mammary epithelial cells. J Diary Sci. 2016;99(4):3016-22

19. Zhang M, Zhao M, Qing Y, Luo Y, Xia G, Li Y. Study on immunostimulatory activity and extraction process optimization of polysaccharides from Caulerpa lentillifera. Int J Biol Macromol. 2020;143:677-84.

20. Sun Y, Gong G, Guo Y, Wang Z, Song S, Zhu B, et al. Purification, structural features and immunostimulatory activity of novel polysaccharides from Caulerpa lentillifera. Int J Biol Macromol. 2018;108:314-23.

21. Septama AW, Jantan I, Panichayupakaranant P. Flavonoids of Artocarpus heterophyllus Lam. heartwood inhibit the innate immune responses of human phagocytes. J Pharm Pharmacol. 2018;70(9):1242-52.

22. Fang $\mathrm{Q}$, Wang JF, Zha XQ, Cui SH, Cao L, Luo JP. Immunomodulatory activity on macrophage of a purified polysaccharide extracted from Laminaria japonica. Carbohyd Polymer. 2015;134:66-73.

23. Abdala DRT, Casas AV, Arrojo AMA, Cardenas C, Dobretsov S, Figueroa FL. Immunomodulatory and Antioxidant Activities of Sulfated Polysaccharides from Laminaria ochroleuca, Porphyra umbilicalis and Gelidium corneum. Mar Biotechnol. 2019;21(4):577-87.

24. Rizki IF, Sinurat E, Fajriah S, Saefudin E. Antioxidant activity of sulfated polysaccharide extract from green seaweed (Caulerpa lentillifera) Makassar, Indonesia. Key Eng Mater. 2020;840:214-20.

25. Barbosa JS, Costa MSSP, Melo LFM, Medeiros MJC, Pontes DL, Scortecci $\mathrm{KC}$, et al. In vitro Immunostimulating Activity of Sulfated Polysaccharides from Caulerpa cupressoides Var. Flabellata. Mar Drugs. 2019;17(2):105.

Article History: Submission Date : 07-04-2020; Revised Date : 22-07-2020; Acceptance Date : 05-10-2020

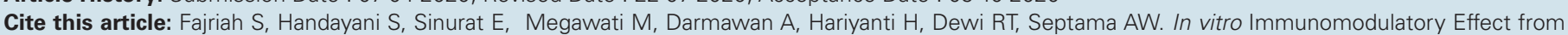

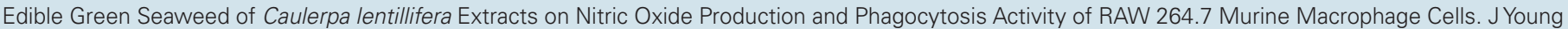
Pharm. 2020;12(4):334-7. 